\title{
The Best Laid Plans...: Jesuit Counsel, Peacebuilding, and Disaster on the Chilean Frontier; The Martyrs of Elicura, 1612
}

\author{
Andrew Redden \\ University of Liverpool \\ A.Redden@liverpool.ac.uk
}

\begin{abstract}
In a context of ongoing warfare on the Chilean frontier in the first decades of the seventeenth-century, the Society of Jesus and, in particular, Luis de Valdivia (d.1642) labored as both missionaries and peace-brokers between the warring sides. Making peace was an act of mercy highlighted in the Constitutions as well as a necessary precondition for evangelization. Nevertheless, in order to develop, champion, and sustain a viable peace process, it was necessary for Valdivia to not just give counsel to the king and the king's representatives, but effectively become a crown agent with the power to make strategic and highly political decisions. This, of course, flew in the face of the Society's own prohibitions on engaging in "reason of state" and also antagonized many whose interests lay in the prolongation of war. The following article charts Valdivia's attempts to balance these spiritual and temporal obligations in the context of the disastrous chain of events that led to the slaughter and enslavement of hundreds of indigenous allies and the killing of three Jesuits at Elicura in 1612. Counsel failed, and the fragile peace-process teetered on the brink of collapse.
\end{abstract}

\section{Keywords}

frontier missions - Chile - defensive war - Mapuche - Anganamon - frontier warfare peace-brokering - apologia - Luis de Valdivia - Elicura - martyrdom

1 Dates for the births, deaths, and terms in office of particular Jesuits have been cited either from Eduardo Tampe, Catálogo de jesuitas de Chile (1593-1767) (Santiago: Ediciones 
See how this [Jesuit] father wages cruel war on us with tricks and offers that war must no longer be waged, because he alone says so, and we know that all the Spaniards want and ask for war and have sent to Spain for [war] to return. And in the meantime this father disarms us, undermining our training and our morale, disbanding our infantry, and dividing us and ruining our customs and practices. And then they will come when we are at our most unprepared, and they will capture us and make us serve [them]. ${ }^{2}$

\section{Violent Borders, Mission, and the Jesuit Predicament}

Suspicion, anger, and systematized interethnic violence were part of the world that the Jesuits of Chile and, in particular, Luis de Valdivia (d.1642), tried to mediate in the first decades of the seventeenth century while attempting to carry out their mission of evangelizing the indigenous peoples of the region. Internecine conflict between the Spanish colonizers and numerous indigenous peoples had been waged for over half a century in the territories south of the city of Concepción and the River Biobío. ${ }^{3}$ In 1598-99, a major indigenous uprising

Universidad Alberto Hurtado, 2008), or the Diccionario histórico de la Compañía de Jesús: Biográfico-temático, 4 vols., ed. Charles E. O’Neill and Joaquín M. Domínguez (RomeMadrid: Institutum Historicum Societatis Iesu-Universidad Pontificia Comillas, 2001).

2 Luis de Valdivia, paraphrasing Anganamon and his allies' reasons to fight against the Spanish, in: "1611 [1621/2?] P. Valdivia, Memorial al Rey," Archivum Romanum Societatis Iesu [hereafter ARsi ], Chil. 4, f. $14^{\mathrm{r}}$. This and, unless otherwise stated, all other translations are my own. The letter is dated 1611 in ARSI but details within the letter confirm that it was written after Valdivia had returned to Madrid and certainly not before 1621 (the year Philip III died) or perhaps the following year (1622). The letter does not specify to which king it was addressed. Philip II favored the Jesuit strategy of defensive war, while Philip IV ruled in favor of those who opposed it and returned to offensive war in 1625. Horacio Zapater, following Toribio de Medina, dates the letter as 1622 and thus written to Philip IV. See Horacio Zapater, $L a$ búsqueda de la paz en la guerra de Arauco: Padre Luis de Valdivia (Santiago: Editorial Andrés Bello, 1994), 121-22.

3 Concepción, founded in $155^{\circ}$ by Pedro de Valdivia, was moved from its original site (which is now the city of Penco) to its present location after a devastating earthquake in 1751. 
destroyed the principal Spanish settlements south of the Biobío. ${ }^{4}$ The first act was to kill the governor Martín García Óñez de Loyola (in office 1592-98) in December 1598 in an ambush at Curalaba. ${ }^{5}$ His severed head was kept as a trophy while "they sent their arrow [...] to various places with their ambassadors and messengers; and it must not have been difficult to persuade the other Indians of their position, because even though they were subject to the Spaniards. [...] they always carried the ardent desire for their own liberty in their breasts." 6

Such was the context into which the newly arrived members of the Society of Jesus were thrust. ${ }^{7}$ Having only established themselves in the colony in 1593, and with the violent death of their patron, the governor García Oñez de Loyola, in 1598 it is perhaps not surprising that Luis de Valdivia, then rector of the newly founded Jesuit college of Santiago, endorsed a petition the following year from the elite of the city of Santiago which argued for the enslavement of indigenous rebels. ${ }^{8}$ After Valdivia was recalled to Lima in 1602 , however, he was persuaded by his Jesuit brethren there of the just nature of the rebellion. ${ }^{9}$ It was at this point that Valdivia began to develop the Spanish colonial policy of defensive war between the years $1604-5$, and then became its vigorous defender until Philip IV (r.1621-65) abandoned it in 1625. During this time, the Jesuit was the lynchpin in the implementation of this strategy whereby the Spanish would retreat to a line of fortifications along the River Biobío and (in theory at least) only lead incursions into the territories south of the river if they or their

4 These settlements were Valdivia, Villa Rica, La Imperial, Osorno, Angol, and Santa Cruz de Coya. Sergio Villalobos refers to Santa Cruz as "Santa Cruz de Óñez": Villalobos, La vida fronteriza en Chile (Madrid: Editorial Mapfre, 1992), 237. See also Alonso de Ovalle, Histórica relación del Reino de Chile y de las misiones y ministerios que ejercita en él la Compañía de Jesús [1646] (Santiago: Pehuén Editores, 2003), 365. Rather than Osorno, Ovalle names Chillán as the one of the six destroyed cities.

5 Eugene Korth, Spanish Policy in Colonial Chile: The Struggle for Social Justice, 1535-170o (Stanford: Stanford University Press, 1968), 76-77. See also Villalobos, La vida fronteriza, 235-37, and Ovalle, Histórica relación, 362-65.

6 Ovalle, Histórica relación, 364 .

7 Royal permission for the establishment of the Society of Jesus in Chile had been initially granted in February 1579 and was reiterated in 1590. Seven were allowed to travel by the royal proclamation but eight or nine actually travelled: Arturo Fontecilla Larraín, Diccionario histórico biográfico colonial de jesuitas chilenos 1593-1767 (unpublished manuscript: Institutum Historicum Societatis Iesu, n.d.), 2-3; see also Rolf Foerster, Jesuitas y mapuches 1593-1767 (Santiago: Editorial Universitaria, 1996), 33-34, and Zapater, Búsqueda de la paz, 20.

8 José Manuel Díaz Blanco, El alma en la palabra: Escritos inéditos del P. Luis de Valdivia (Santiago de Chile: Ediciones Universidad Alberto Hurtado-Pontificia Universidad de Chile, 2011), 30; Zapater, Búsqueda de paz, 109; Korth, Spanish Policy in Colonial Chile, 85-91.

9 Díaz Blanco, Alma en la palabra, 30-31; I am grateful to Andrés Ignacio Prieto for drawing my attention to Valdivia's early change of heart. 
indigenous allies were themselves attacked. The Jesuit's role of counsellor and agent to Philip III (r.1598-1621) and successive viceroys and governors of Chile was central to Spanish policy in the area, and it is this that shall be the focus of the following article.

As might be expected, Valdivia's plan to implement a new colonial strategy for Chile, was vehemently contested by both secular and clerical Spanish residents there. Temporarily beaten by such strong opposition, he returned to Lima in 1606 before heading to Spain in 1609 to seek formal approval of his plan for a negotiated settlement from the court of Philip III and the Council of the Indies. ${ }^{10}$ The plan, which also lobbied the crown to end obligatory labor service for indigenous peoples in the Americas, similarly received the enthusiastic backing of the Jesuits in Paraguay and Valdivia's superior, the provincial Diego Torres Bollo (d.1638; in office 1607-15). ${ }^{11}$ This was fundamental to winning over the superior general Claudio Acquaviva (1543-1615, in office 1581-1615). Ultimately, in 1610, the Spanish court appointed Valdivia as the crown representative with full powers to implement the new strategy of defensive war and the subsequent peace treaty with the insurgent Mapuche. ${ }^{12}$

Valdivia's multilayered role flew in the face of a key norm of the Society of Jesus: namely, he acted as the agent of a secular authority. The Constitutions were seemingly clear what his priorities should have been: "So that the Society may be able to devote itself more entirely to the spiritual pursuits pertaining to its profession, it should abstain as far as possible from all secular employments [...] through not accepting such burdens and not employing itself in them because of any requests."13 Nonetheless, when the court named him ecclesiastical administrator (vicar general) of the diocese of Concepción until such time as a bishop might be properly named and consecrated, Acquaviva appointed Valdivia independent superior of the missions already established and those yet to be established south of the Biobío. ${ }^{14}$

10 He won the support of successive viceroys for his plan: Luis de Velasco, the Marquis of Salinas [in office 1596-1604], Gaspar de Zúñiga y Acevedo, Count of Monterrey [in office 1604-6]) and Juan de Mendoza y Luna, the Marquis of Montesclaros [in office 1607-15]). Díaz Blanco, Alma en la palabra, 35-37.

11 The Jesuit mission to Chile was incorporated into the newly founded province of Paraguay in 1607 .

12 Díaz Blanco, Alma en la palabra, 39-44.

13 John Padberg, ed., The Constitutions of the Society of Jesus and their Complementary Norms: A Complete English Translation of the Official Latin Texts (St. Louis, MO: Institute of Jesuit Sources, 1996), Part VI, no. 591, 258.

14 Philip III had tried to name Valdivia bishop of Concepción but Jesuits were prohibited from seeking a prelature and Acquaviva made it clear that he would block the appointment. Padberg, Constitutions, Part X, no. 817, 404. Korth clarifies in a note that 
Valdivia, then, transitioned from the role of counsellor to the Spanish authorities (the Chilean governors, viceroys of Peru, and the king) to that of imperial agent entrusted with implementing his own policy and chief negotiator to the insurgent indigenous leaders and their warriors..$^{15}$ This essay will explore the resultant conundrum: his endeavor to fulfil the Jesuit obligation to become peace-maker in order to further the process of evangelization required Valdivia to take on the role of imperial counsellor and diplomat, a role which, in turn, was likely to put him at odds with the Constitutions of his own order. ${ }^{16}$

Valdivia's role as counsellor, mediator, and peace-builder, was not, of course, limited to the Spanish. For his strategy to work, he needed to persuade both sides in the conflict of its viability. This article, therefore, also brings into the discussion the response of certain indigenous groups to Valdivia's representations for peace and will set this analysis against the build-up to one particular event- the disaster of Elicura in December 1612. The event left three Jesuits (two priests and one novice) dead and hundreds of indigenous Elicurans slain or enslaved. As might be expected, Elicura came close to entirely derailing the peace-process initiated by Valdivia, and yet, against the odds, the strategy of defensive war remained in place until 1625 .

The article will follow some of the threads that led into the subsequent tangle and will discuss how Valdivia's careful implementation of his strategic plan through counsel, systematic mediation and political intervention was so nearly and so easily upset by unforeseen events like Elicura. Throughout, the

"diocesan headquarters were officially transferred from La Imperial to Concepción on Feburary 7, 1603." Korth, Spanish Policy in Colonial Chile, 123-25.

15 Paolo Broggio investigates the theme of Jesuits as mediators in a study that spans the seventeenth century. He makes parlamentos (parliaments—essentially, summit meetings in which Mapuche leaders and warriors gathered with Spanish representatives to discuss terms for peace) a key focal point of his discussion. This article builds on these broader ideas and add specific detail by focussing in particular on the events taking place in and around the years 1612. See Paolo Broggio, "I gesuiti come mediatori nella guerra d'Arauco: Il padre Luis de Valdivia e il sistema dei Parlamentos de Indios (XVII secolo)," Archivum historicum Societatis Iesu 74, no. 147 (2005): 57-89.

16 Broggio, "Gesuiti come mediatori," 68. Broggio suggests that Valdivia's vociferous activity in strategic matters on the Chilean frontier, so blatantly going against the norms of the Society are likely to have "irritated" the curia (Broggio, "Gesuiti come mediatori," 69). It is perhaps also important to bear in mind that Acquaviva's appointment of Valdivia to the post of superior of the Biobío missions deliberately gave him an autonomy that would enable him to carry out his work as crown peace-broker. As Broggio points out, Acquaviva instructed Valdivia to place himself under the authority of the provincials of Paraguay and Peru, but given the speed with which decisions on the frontier needed to be made, this was very difficult to do in practice. See also Korth, Spanish Policy in Colonial Chile, 128. 
article will consider how the damage brought about by such events was exacerbated by the conflict between the spiritual and political obligations of Valdivia and his fellow Jesuits on the Chilean frontier.

\section{Jesuit Counsel and Peacemaking}

The Constitutions of the Society of Jesus laid out in detail the expected role of Jesuit missionaries. They were to prioritize spiritual activities such as participation in the liturgy, preaching, teaching, and giving spiritual exercises, yet they were also to "occupy themselves in corporal works of mercy" such as "assistance to the sick, especially in hospitals, [...]; the reconciliation of quarrelling parties; and $[. .$.$] doing what they can for the poor and for prisoners in$ the jails." ${ }^{17}$ The annual letters sent to Rome from all the provinces of the Americas document the adherence of Jesuit missionaries to these key fundaments of the order. "To create friendships" between individuals in conflict became a familiar component of these letters. ${ }^{18}$ With the Chilean frontier in open warfare, however, an act of mercy such as making peace between two individuals, no matter how bitter their rivalry, almost paled into insignificance alongside that of making peace between two warring peoples. How much more merciful would it be to bring to an end decades of warfare that had caused untold suffering on the Chilean frontier? In the words of the Constitutions themselves: "the more universal the good is, the more it is divine."19

There was also a fundamentally pragmatic reason for wanting to bring about a sustainable peace in Chile. The underlying objective of the Society of Jesus stated in the Constitutions was "with God's grace [...] to labor strenuously in giving aid towards the salvation and perfection of the souls of [the members] neighbors." 20 This goal to "aid souls to reach their ultimate and supernatural end" simply could not be carried out in circumstances in which those very

17 Padberg, Constitutions, Part viI, no. 650, 298.

18 As just one of many such examples the annual letter from Peru, 1603, states: "A soldier in the same prison as another said he had made a friendship for the time-being [after being] offended by the other in [a] most serious matter of honor. And the injured party twice had his dagger in his hand to take the life of his enemy and without doubt he would have killed him if one of our fathers had not stopped them by bringing them together, reminding them of the firm and stable nature of friendship which certainly was necessary. With this grave harm was averted." Rodrigo de Cabredo, "Letras Annuas de la Provincia del Peru por el año de 1603," ARSI, Per. 12, f. $323^{\text {r }}$.

19 Padberg, Constitutions, Part VII, no. 622, 286.

$20 \quad$ Ibid., General Examen, no. 3, 24. 
people they wished to evangelize through preaching, teaching, ministering the sacraments, and spiritual counsel, were at war with and at constant risk of being enslaved by those who claimed to be Christian. ${ }^{21}$ In a brief written in 1604 to the viceroy of Peru, Luis de Velasco, Valdivia took pains to remind him that the root causes of the war were the unjust oppression of the indigenous population through enforced labor service and that this, together with the war which resulted, greatly inhibited their acceptance of Christian doctrine. Valdivia stressed that "if [only] the war should end as is to be hoped, the general impediment that existed in Chile to harvesting fruit amongst both the peaceful and warlike Indians would be removed. ${ }^{22}$

Peace was thus a necessary precondition to build the trust needed to properly persuade the indigenous groups who were fighting, being killed, or enslaved by the Spanish of the merits of Christianity. The Society of Jesus therefore argued vociferously against the perpetual warfare that was being waged for the purposes of enrichment and Luis de Valdivia effectively assumed the leadership of this campaign. The alternative Jesuit strategy was instead to be defensive, one that would allow for the movement of missionaries under truce and would prohibit the enslavement of the indigenous groups of Araucanía. Valdivia reiterated his counsel to Velasco and his successor Gaspar de Zúñiga that "the only effective way to put a quick end to the war and bring peace to Chile-something which in all conscience is required by charity, justice, and prudence - is to begin to undo the injustices and insults which are oppressing the peaceful Indians in Chile." ${ }^{23}$

For Valdivia and those Jesuits on the frontier who worked to put his strategy into practice, peacemaking was nonetheless difficult to pass off as merely being for the purposes of evangelization or even as a supreme act of mercy as they, effectively, became the agents of the Spanish crown in arranging the summits (or parliaments) in which they themselves would negotiate the terms of the peace on behalf of the king. Such activity was assuredly in contravention of the above-cited Constitutions that prohibited a Jesuit from accepting secular employment. This was taking "counsel" far beyond the spiritual remit

21 For the quoted goal see Ibid., Part X, no. 813, 400.

22 Luis de Valdivia, "Memorial a Luis de Velasco y el Conde de Monterrey, Lima, 1604," in Díaz Blanco, Alma en la palabra, 97.

23 Luis de Valdivia, “Lima 4 Dic 1604: Relacion q' hizo el P.e Luys de Valdiuia lector de theologia del Coll.o de Lima por orden de sus sup.es y de los ss.es Virreyes don luys de Velasco y conde de MonteRey su sucessor. Sobre agrauios que receven los yndios de paz sin agrauios," ARsi, Chil. 4, f. $2^{\text {r }}$. Luis de Velasco (the marquis of Salinas) was replaced by Gaspar de Zúñiga (the count of Monterrey) as viceroy of Peru in February of 1604. 
of the Society of Jesus. It is worth noting, though, that the constitutional prohibition was immediately followed by an equivocation that read: "This should be observed as far as possible. But the authority to dispense for a time, in a case of necessity and importance for the end of divine service which is sought, should be left to the superior [my italics]."24

Even Saint Ignatius (d.1556) had been ambiguous on this point. On the matter of whether Jesuits should act as confessors to princes-a role in which the boundary between counsel on matters of conscience and matters of state could often become very blurred indeed - the founder of the Society had argued that Jesuits should minister to all, the powerful as well as those of low status, and that it was more important to give spiritual assistance to the head of the body than to the members, when the members (the subjects) were governed by the head (the prince). ${ }^{25}$ Instructions issued in 1548 by the secretary of the Society, Juan Alfonso de Polanco (1517-76, in office 1547-73) were similarly ambiguous with respect to the type of tasks that a Jesuit might acquiesce to do:

If he is sent indefinitely to help in whatever way he can any town, diocese, province or kingdom, and that way advance as much as he can the honour of God, he must [...] do so with great desire to achieve that end and with much willingness to take up such a great enterprise, putting behind him all negligence and faintheartedness [my italics]. ${ }^{26}$

There could be little doubt that, after persuading the court of the viability of his strategic plan in 1610, Valdivia's subsequent appointment by the king to implement that strategy was taken up firmly in the spirit of Polanco's instruction. The problem was that by this time both the fifth (1593-94) and sixth (1608) general congregation of the Society of Jesus had ruled against Jesuits becoming involved in politics. The fifth general congregation was particularly clear that, under pain of dismissal from office and the depravation of electoral rights, Jesuits were not "for any reason to dare or presume to become involved in the public and secular affairs of princes which have to do with, as they say, reason

24 Padberg, Constitutions, Part vi, no. 592, 258.

25 Robert Bireley, The Jesuits and the Thirty Years War: Kings, Courts and Confessors (Cambridge: Cambridge University Press, 2008), 27.

26 Juan Alfonso de Polanco, "Industrias con que uno de la Compañía de Iesús mejor consiguirá sus fines: Cómo se an de auer los que atienden al próximo en esta Compañía de Iesús para maior seruicio diuino y bien de las ánimas," in Monumenta Historica Societatis Iesu, Polanci complementa, vol. 2 (Madrid: Gabriel López del Horno, 1917), 776-807, here 782 (" $2^{\mathrm{a}}$ Industria"). 
of state."27 There could be no question that the negotiation of peace treaties between the Mapuche and the Spanish — especially when this involved strategic decisions such as with whom the Spanish might agree peace treaties and when and where to dismantle frontier forts - was tantamount to a Jesuit actively and openly engaging in reason of state. ${ }^{28}$ Rather than peace being the means to the end of successful evangelization of the frontier, the task so appeared to consume Valdivia that peace-building, or in other words, reason of state through the negotiation and successful implementation of peace-treaties, appeared to become the end in itself. This apparent confusion of goals was thrown into stark relief by the events that followed.

\section{The Parliaments of Longonabal and Nancu}

When Valdivia left the court in 1611 and returned to Chile armed with the extensive powers the crown had granted him to implement his strategy of defensive war, he threw himself wholeheartedly into the substantial effort to persuade the warring sides to implement the plan. In this he acted as counsellor and Spanish agent in the service of Viceroy Montesclaros, the newly appointed governor, Alonso de Ribera (d.1617; in office 1612-17), whose appointment Valdivia specifically requested of Philip III, and field commanders such as Álvaro Núñez and Francisco Galdames with whom he was to work closely. At the same time, as the representative of the crown tasked with bringing peace to the frontier, he also acted as counsellor to the various indigenous leaders and kinship groups along the frontier then up in arms against the Spanish. ${ }^{29}$

On his arrival in Chile, Valdivia wasted no time in journeying to the frontier and sending out messengers across the region to carry word to various

27 Decree 79, Institutum Societatis Jesu, 2:288, cited and translated by Bireley, Jesuits and the Thirty Years War, 28. Bireley continues by expounding how not even this seemingly very clear prohibition was able to eliminate ambiguity from Jesuit practices.

28 For a full discussion of the definition of "reason of state," especially in a Jesuit context, see Harro Höpfl, Jesuit Political Thought: The Society of Jesus and the State, c.1540-1630 (Cambridge: Cambridge University Press, 2004), 84-97. For the purposes of this essay, I use the term following Höpfl's preliminary definition of "reason of state" as "thinking about or discussing the business of ruling, or the methods or ways of acting, or reasons for acting, that were typical of rulers or regimes" (Höpfl, Jesuit Political Thought, 84).

29 Álvaro Núñez was the father of the chronicler Francisco Núñez de Pineda y Bascuñán. See Cautiverio feliz, 2 vols., ed. Mario Ferreccio Podestá and Raïssa Kordic Riquelme (Santiago: Ril Editores, 2001). 
indigenous groups of the king's willingness to negotiate a treaty. ${ }^{30} \mathrm{He}$ was counting on the war-weariness of certain sectors of the insurgent indigenous populations and their readiness to at least consider listening to the new terms. He was not wrong in this assumption. The fort of Arauco was soon approached by five indigenous warriors armed with lances and daggers. They refused to speak to the field commander Álvaro Núñez and insisted they would only speak with the Jesuit. ${ }^{31}$ When Valdivia crossed the river to meet them they threw their lances into the ground as a sign they had come in peace, greeted him with an embrace and, on behalf of their own leaders, discussed the terms that Valdivia had so recently disseminated throughout the region. They asked for his permission to return to their lands that they had been forced to leave as a consequence of the war. However, they refused outright

to move to reductions beyond their own lands [because this] was a very violent thing and in no way would they do so, and [stated] that what had made the inhabitants of all the land at war the happiest was the promise that they would be left free in their own lands without having to serve anyone, something which they would not do whilst the sun moved across the sky. ${ }^{32}$

According to Valdivia's report, they called him a great benefactor and declared that he should not fear to journey to their territories, as they would not reject the offer of such a great king as that of the Spaniards. They also warned the Jesuit that he would be summoned to a parliament to be attended by the warrior leaders of Catiray. Valdivia meanwhile, as both counsellor and de facto royal representative, advised them to return to their lands and promised that the field commander Álvaro Núñez would no longer lead raids against them. ${ }^{33}$

The subsequent parliament was such a serious matter that Valdivia himself needed to take counsel with the military officers, interpreters, and chaplains present at the fort of Arauco. ${ }^{34}$ He would be going into enemy territory with little to no protection and would be trusting his life to indigenous warriors

30 Luis de Valdivia, "Copia de la entrada a los Yndios de Guerra del P.e Luis de Valdiuia

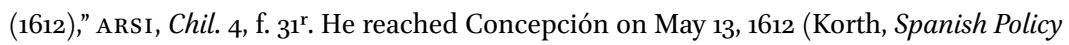
in Colonial Chile, 131).

31 Valdivia, "Copia de la entrada," f. $31^{\mathrm{r}}$.

32 Ibid.

33 Ibid.

34 He mentions the field commanders Álvaro and Galdamez, the captains Negrete and Hercales, don Pedro de Guzmán, the interpreters Góngora and Pinto, and the chaplains who ministered to the forts of Arauco, Lebo, and Paicaví. Ibid., ff. $31^{\mathrm{r}-\mathrm{v}}$. 
who were enemies of Spain. Nevertheless, the potential benefits outweighed the risks and given that "all those of Longonabal and, he had heard, the three ulmenes [senior leaders] of Catiray were waiting" he resolved to go to the summit. ${ }^{35}$ In a somewhat bizarre role reversal, Valdivia the Jesuit priest left to negotiate with the Mapuche, while the soldiers, according to his report, remained in the fort praying for him "[for] many hours" before the Blessed Sacrament exposed on the altar of the chapel. ${ }^{36}$

The signs that Valdivia's plan might work were positive. On arriving at the parliament of Longonabal, he wrote that he was "embraced with great joy," while one of the senior warrior leaders present named Guasquimilla, proclaimed that the general happiness that had spread throughout the lands of war was such that "even the grass seemed to undulate with joy."37 Valdivia also reported that he was given titles such as Father and Mother and Anilmapubue, which he glossed as "the one who settles things, and peace-maker of the kingdom." Nevertheless, while the leaders gathered at Longonabal believed the terms that he was offering on behalf of the king, they told the Jesuit that their warriors at Nancu were more suspicious and suspected a trap. They feared that "so much good, and peace without obligatory labour service was to trick them as they had been tricked in the past" and they would be subsequently enslaved. ${ }^{38}$ Valdivia's counsel could not, therefore, stop with the leaders. He would have to face the warriors in person and once again place his life on trust.

The Jesuit now hesitated. He informed them of his deep gratitude that such senior leaders had come to speak with him. Nevertheless, in what appeared to be seeking a safe way out, he told them he was obliged to return to Concepción to inform on his progress so far. The Mapuche leaders countered that it would be better to go first to Nancu to speak to the warriors and then report back, in particular as the ulmen of Purén, Inabila, was waiting to see what his peers in Catiray were able to negotiate with Valdivia, the king's representative. ${ }^{39} \mathrm{~A}$ great deal hung in the balance, and caught out by circumstance, the Jesuit had no choice but to acquiesce and was led "by closed, harsh and secret ways" to the next parliament where he was (to his relief) greeted with a cinnamon branch, "a sign of peace amongst them." ${ }^{\text {"0 }}$

\footnotetext{
35 Ibid., f. $31^{\mathrm{v}}$.

36 Ibid. Valdivia reports that he was accompanied only by Captain Pinto who was to act as an interpreter and a soldier named Juan Martínez to serve his needs.

37 Ibid.

38 Ibid.

39 Ibid

$40 \quad$ Ibid., f. $32^{\mathrm{r}}$.
} 
The summit lasted eight hours according to Valdivia's own report. The terms of the peace were reiterated and disputed until an experienced warrior named Carampamgui, took the floor to give thanks for Valdivia's presence. He continued by arguing that if the king was truly suggesting that they would neither be forced into labor service, nor would the Spaniards wage war on them, then these were terms they might willingly accept. He then called on Valdivia to stand and speak to those present. ${ }^{41}$

Given that this was arguably the culminating moment of Valdivia's intensive efforts over the previous eight years, and also given the rather precarious situation that he was currently in, the Jesuit's reply ranged between extremely courageous, utterly foolhardy and simply astounding. He flatly refused on a point of principle to stand and take the floor arguing that he

firstly, was the priest of the great God, creator of all the world [...] and for this reason all men in the world must respect [him]; and, secondly, [he] was the messenger of the greatest king and lord of the world, who was the King of Castile, don Felipe, our lord, and that [Valdivia's] mouth was his [the king's] mouth that spoke there. And for this [he] was owed respect. ${ }^{42}$

Valdivia the counsellor, the peace-maker, the negotiator, was playing an expert yet very dangerous game of brinksmanship and was seemingly prepared to take the negotiations to the wire, potentially insulting his hosts in order to stamp his authority on the proceedings. Considering how badly wrong things might have gone at that moment, Carampamgui's response was remarkably gracious. They knew, he said, that the [Jesuit] fathers were respected and were also willing to respect a king who offered them such good terms. What was more, they also knew how tired the Jesuit must be having journeyed as far as he had come and so that Valdivia did not tire himself out more by having to project his voice, the Mapuche leader proposed that everyone else get up and move closer to the Jesuit who remained seated in the center. ${ }^{43}$

Having scored that point, Valdivia the rhetorician came into his own. He wrote in his report that his speech given through the interpreter lasted for three hours in which he summarized the story of his time in Chile and how he had seen their suffering throughout the region, "exaggerating a great deal the fault of the Spaniards, the compassion [he] felt for them [the Mapuche], and the sermons [he] had preached to the Spaniards to persuade them to stop

\begin{tabular}{ll}
\hline 41 & Ibid. \\
42 & Ibid. \\
43 & Ibid.
\end{tabular}


harming the Indians." ${ }^{34}$ Here was an experienced orator who knew precisely how to win the sympathy of his audience. He described how in his sermons he had threatened the Spaniards with hell and pleaded with them to recognize that "the Son of God became man [...] and died on the cross as much for the Indians as for yourselves [the Spaniards], rising from the dead and ascending to the Heavens to open the gates so that the souls of the Indians could enter just like you [Spaniards]." ${ }^{\prime 4} \mathrm{He}$ then proceeded to recount to the gathered warriors the protracted negotiations and planning he had done with three different viceroys, the fourteen months he had spent at court in audiences with the queen and the king, counselling the monarchs that the Mapuche would never be suppressed by war, and that it was better to leave them in their lands without demanding labor service and instead send priests to minister to them. ${ }^{46}$ Valdivia continued his tour-de-force, describing how the king listened to his counsel and gave him letters delegating his authority to negotiate the peace on their behalf. He then told them he was awaiting the arrival of the new apo or governor, Alonso de Ribera, who also wanted peace. ${ }^{47}$

Well aware of the dangers of appearing to negotiate from a weak position, Valdivia also warned the gathered warriors that Ribera had previously served as governor (1601-5), and that while he now wanted peace, they might well remember he still knew how to wage war and that during his last term in office he had reconquered the lands that had been lost around the Biobío: "You have feared no one as much as this lord who imposed the forts of Lebo and Paicaví [and various other strategic outposts] on you." ${ }^{48}$ Now, Valdivia pressed on, this governor, who was eminently capable of waging war, was returning merely to obey the king's letters of authority that the Jesuit held in his possession and to take those forts away. Having placed himself at the center of Spanish power in the region, he then moved towards the climax of his speech with a rhetorical (if somewhat risky) flourish arguing that given the king's generosity and given that he saw clearly that all the Araucanian Indians wanted peace and hated war: "Tell me warriors, which one of you would be the first to cut off my head for bringing you this good news?"49 These were to prove fateful words.

44 Ibid.

45 Ibid.

46 Ibid., f. $3^{2}{ }^{\mathrm{r}-\mathrm{v}}$.

47 Apo is the Quechua term for "Lord" and reflected the hierarchical Inca society. Quechua was the language of the Inca civilization of Peru. There was no equivalent term in Mapundungun (the language of the Mapuche) given the more horizontal societal structures that existed amongst the Mapuche.

48 Valdivia, "Copia de la entrada," f. $32^{\mathrm{v}}$.

49 Ibid. 


\section{The Martyrs of Elicura}

As might be expected, Valdivia did not win over the entire parliament. His smooth rhetoric was contested by an astute warleader named Llamcamilla who declared that Valdivia did not have the authority to remove forts and, if the forts were still in place then there would be no doubt that labor service would be enforced. ${ }^{50}$ At this point the horizontal faultines amongst the Mapuche became much clearer when he declared that the ulmenes were happy with the terms offered only because they knew that they would not have to serve due to their high rank. All those of lower rank would have to pay the consequences. He accused both the ulmenes and the Spaniards of treachery and, with his contingent of warriors, stormed out of the summit. ${ }^{51}$

Minor setbacks such as this notwithstanding, Valdivia's drive towards a sustainable peace on the frontier gained considerable momentum. A significant proportion of the populations in conflict with the Spanish were at least willing to consider the new terms, and a notable number of those again expressed a willingness to accept them. In September of 1612, Valdivia described to the king how he had received positive responses from indigenous leaders from across the provinces of Purén and the cordillera and that all offered peace on the condition that the promises Valdivia had made on the king's behalf were to be kept. ${ }^{52}$

Peace on the frontier, however, could never be secure if he could not gain the consent of the leader of the 1598 insurrection, Anganamon. Conversely, if Valdivia could win over Anganamon, the most powerful leader in the region, he would assuredly end the conflict as the other insurgent leaders would follow suit. If ever there were need for proof of Valdivia's almost total immersion in reason of state at this point one need look no further than how he played his ace-card-Anganamon's co-insurrectionist, Tureulipe, who had been captured in a skirmish some months previously - in order to bring Anganamon to terms. Using an exchange of prisoners to demonstrate good faith, they would be able to initiate a dialogue. So it was arranged that Tureulipe, together with

$50 \quad$ Ibid., f. $33^{\mathrm{v}}$. Valdivia called him a "captain."

$5^{1}$ Ibid. His concerns were legitimate, but, arguably, there is an additional subtext to the anger of the less-senior warriors. It was through warfare that they gained recognition and prowess in their own communities. While the ulmenes may want peace to protect their people from further damage, the younger or less senior warriors needed to go to war in order to advance their status.

$5^{2}$ Luis de Valdivia, “Carta a Felipe III, Concepción, 30 de septiembre de 1612," in Díaz Blanco, Alma en la palabra, ${ }^{155^{-}} 5^{6}$. 
two other captured warriors, would be exchanged at the fort of Paicaví for Spanish prisoners taken by the Mapuche and, Valdivia stressed to the governor Alonso de Ribera: "This was not for the interests of one or two captive Spaniards, rather for many - for the peace of the kingdom."53 "With this prisoner, who was highly respected by the enemy," wrote Valdivia to the king in February 1613, "the doors were opened to negotiation with Purén." ${ }^{54}$ Valdivia personally oversaw the exchange and, in October 1612, wrote to the governor, Alonso de Ribera: "I leave at midday today for Paicaví in the company of Captain Negrete, taking Tureulipe with me and with whom I have spent many hours since arriving here." 55

For his part, Anganamon released the Spanish prisoners don Alonso Pérez de Quesada y Guzmán, sergeant Juan de Torres and a ten-year-old girl named Isabel Basurto on November $10 .{ }^{56}$ To Valdivia, it seemed that all was going to plan; Anganamon and Tureulipe left for the south to rally their allies and convince them that this time the Spanish had offered a meaningful treaty that they could accept and through an agent they could finally trust. Finally, Valdivia's counsel and negotiations, against the odds, had seemingly succeeded and the frontier was now at peace.

It was at this point that the threads that Valdivia was so carefully weaving together became entangled and snapped. Torres, while staying at Anganamon's residence as he journeyed towards his freedom, had the temerity to start an affair with one of Anganamon's wives, also a Spanish captive, who took advantage of her captor-husband's absence and fled to the fort of Paicaví to join Torres. ${ }^{57}$ Worse still for the fragile peace, she took her daughter by Anganamon and two other of his wives and another child with her. On arriving at the fort, they asked for baptism. At once the mutual compatibility of Jesuit

53 Luis de Valdivia, "Carta a Felipe III, Fuerte de Buena Esperanza, 20 de febrero de 1613," in Díaz Blanco, Alma en la palabra, 191; Valdivia, "Carta a Alonso de Ribera, Arauco, $3^{1}$ de Octubre de 1612," in Díaz Blanco, El alma en la palabra, 179.

54 Valdivia, "Carta a Felipe III, [...] 20 de febrero de 1613," 191.

55 Luis de Valdivia, "Carta a Alonso de Ribera, Arauco, 31 de Octubre de 1612," in Díaz Blanco, Alma en la palabra, 179 .

56 Valdivia, "Carta a Felipe III, [...] 20 de febrero de 1613," 191.

57 "When Sergeant Torres passed by the house of Anganamon on his way to being ransomed, he fell in love and wished to marry a captive Spanish woman who was the wife of Anganamon and with whom she had a nine-year-old daughter. And he [Torres] persuaded her to flee. She did that afterwards when Anganamon was away negotiating the peace and she brought her daughter with her and two pagan wives of Anganamon with their little children, who crossed over asking for baptism" (Valdivia, "1611 [1621/2?] ... Memorial al Rey," f. $19^{\mathrm{r}}$ ). 
reason of state in Chile and the project of evangelization collapsed. Reason of state dictated that the women's request for baptism be ignored so as not to put at risk the fragile peace that Valdivia and his fellow Jesuits had worked so hard to create. The obligation to save souls, however, dictated that the women should be catechized and baptized. Notwithstanding the potential repercussions, spiritual obligations trumped political responsibilities and the women and children were baptized in accordance with the primary objective of the Society of Jesus to "aid souls to reach their ultimate and supernatural end, the means which unite the human instrument with God and so dispose it that it may be wielded well by his divine hand." 58

As might be expected, Anganamon was enraged by this turn of events. This was clear evidence, once again, of the perfidiousness of the Spanish. He placed his warriors on a war-footing and demanded the return of his wives and children. Given the scale of the insult, the war-leader's initial response was remarkably constrained. ${ }^{59} \mathrm{He}$ knew that the Spanish would never return one of their own to captivity, and even said that they could keep his daughter by his Spanish wife. Nevertheless, under the terms of the treaty that had been agreed all fugitives who fled from either side were to be returned. ${ }^{60}$ The Spanish side nonetheless broke these terms on the grounds that to send the women back would risk their souls through apostasy. ${ }^{61}$ Valdivia himself stated that, such an action would be "impossible as it was against the law of God to return them when he [Anganamon] was living in sin with them and when they and the young daughter had asked for baptism." ${ }^{22}$ To further add to the moral dilemma, testimonies later stated that it was common for those who had tried to defect to the Spanish to be killed and to send the women back to Anganamon would

58 Padberg, Constitutions, Part X, no. 813, 400.

59 The son of the field commander Álvaro Núñez, Francisco Núñez de Pineda y Bascuñán wrote how he was shocked into silence when during his own captivity as a youth he heard Anganamon tell his side of the story. Núñez de Pineda y Bascuñán, Cautiverio feliz, vol. 1, "Discurso 2, capítulos 11-12," 416-20. Anganamon's account retold by Núñez de Pineda was used as evidence in the cause for beatification of the three Jesuits martyred in Elicura in 1612: Archivio Segreto Vaticano [hereafter Asv], Congr. Riti, Processus 4640: Vecchi, Martini, Aranda, ff. 193-96.

6o Valdivia, "1611 [1621?] [...] Memorial al Rey," f. 18v".

61 Ibid.

62 Luis de Valdivia, "Mayo 1612-Nov 1613, Relacion Breue de lo succedido en la pacificacion del Reyno de Chile por los medios que su mag[esta]d cometio al S.r Marques de Montesclaros Virrey del Piru que llebo a su cargo el Padre Luis de Vald[ivi]a de la Compania de Jhs desde 13 de mayo de 1612 hasta princ[ipi]os de nouie[mbr]e de 613 años," ARSI, Chil. 4 , f. $41^{\mathrm{r}}$. 
have been an effective death sentence. As such, it was suggested, the women requested baptism precisely because they feared they would be killed and that in becoming Christian, they anticipated they would be safe. They pleaded with the Jesuits and the Spanish in the fort of Paicaví not to be sent back as they were in fear of their lives. ${ }^{63}$ While the women may well have requested baptism for non-spiritual reasons, the Jesuits in Paicaví, bound as they were by moral and spiritual obligations, could not be complicit in the potential homicide of the women - a mortal sin - in order to preserve the peace, a specific political goal.

Thus matters of the spirit superseded reason of state and, in this instance, Valdivia and his fellow Jesuits prioritized spiritual counsel over and above that of political expediency. Yet the momentum gathered by Valdivia's peaceprocess could not be so easily halted. A contingent including sixty-three warriors and fifteen leaders from the region of Elicura (one of whom was the father of one of Anganamon's wives who had fled) arrived at Paicaví to discuss terms with the Spanish. ${ }^{64}$ They made three demands: firstly that as a sign of good faith that the Spanish were to dismantle the fort of Paicaví; secondly that Jesuits were to come back to Elicura with them; thirdly that the wives and children of Anganamon were to be returned. If the Spanish were to agree to these terms then they could have their peace. ${ }^{65}$

Valdivia later explained to the king that he and the governor agreed to the first demand, notwithstanding the strategic importance of the fort in the region. They already had received orders from Viceroy Montesclaros that it was to be dismantled so Valdivia reasoned that for the sake of agreeing the peace, it could be removed as early as that summer but, crucially, rebuilt nearby in a location where "it would be more damaging to the enemy."66 The second, he writes, was also difficult to agree to, but after a long meeting in which he consulted the opinions of five other Jesuit priests, "taking into consideration a great deal and pondering the pros and contras" it was decided that "it was not merely convenient but also necessary for the service of God and His Majesty and for the good of this kingdom." ${ }^{\prime 7}$ There were, Valdivia wrote to the king, benefits that could be had from Jesuits entering these territories both with regard to the ransom of captives and also in "ministering to the souls of [the captives']

\footnotetext{
63 ASv, Congr. Riti, Processus 4640, ff. 96-97.

64 Valdivia, "Carta a Felipe III, [...] 20 de febrero de 1613," 192.

65 Ibid.

66 Ibid., 193.

67 The five priests were: Horacio Vecchi, Augustín de Villaça, Martín de Aranda, Gaspar Sobrino and Rodrigo Vázquez. Valdivia, "Carta a Alonso de Ribera, Arauco, 31 de Octubre de $1612, " 172$.
} 
and the many Christian Indians that there are." ${ }^{28}$ Therefore it was decided that the two priests Horacio Vecchi and Martín de Aranda, together with the novice Diego de Montalbán should journey back to Elicura with the delegation, trusting, rather naïvely, that the scandal created by the defection of the women would dissipate and that the priests would be safe. ${ }^{69}$ To the third demand, however, there could be no compromise: the souls of the women, nor those of the Jesuits and Spanish commanders could not be jeopardized by handing the women over to apostasy or death. The Jesuits instead would try to negotiate with Anganamon to persuade him to become Christian (in which case he might choose one wife with whom to live a Christian life together) or to accept suitable compensation..$^{70}$

Valdivia had refused to send the women to their deaths, but in trying to continue the work of peacebuilding while containing the damage from this unexpected turn of events he effectively condemned his three subordinates to theirs. On hearing that the three Jesuits had entered Elicura with his one-time allies, Anganamon attacked on December 14, 1612, killing the Jesuits, slaying scores of warriors and leaders of the community, including the ulmen of the region, Coñuemanque (his one-time brother in law), and enslaving over a hundred women and children. ${ }^{71}$

\section{Conclusion}

The harm that has been done by seeing us [the Spaniards] divided in opinion has been very great. And because of this Inabilu sent me a message asking if there were two kings in Castile, one who offered peace and the other who wanted war. ${ }^{72}$

After so many years of meticulous and intensive labor-counselling and lobbying through letters, face-to-face meetings, sermons and summits-something as frivolous as an impulsive love affair combined with the much more weighty spiritual Jesuit imperative to save souls through baptism carried the frontier once again to the brink of warfare and brought into stark relief the contradiction between spiritual obligation and political expediency.

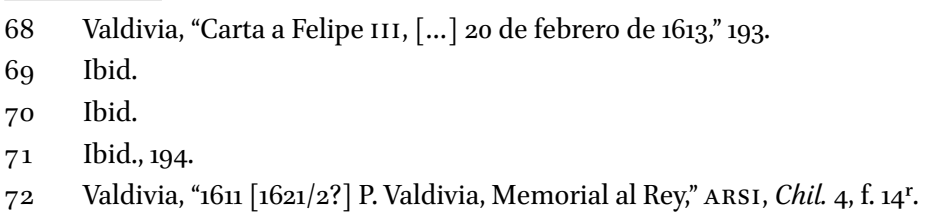


Anganamon and his allies made to punish all those who had betrayed their side and signed peace with the Spanish, while those Spaniards opposed to the peace process clamored for retribution. The bellicose discourse of the Spanish settlers opposed to Valdivia's plan filtered across the border causing very reasonable hesitation on the part of those indigenous groups considering the Jesuit's terms. Many Spaniards who cautiously supported Valdivia's approach, meanwhile, including the governor Alonso de Ribera, shocked by the violent attack against the priests, or perhaps merely waiting for a pretext, withdrew their support for his peace plan and joined the reinvigorated campaign for renewed warfare. Valdivia, a Jesuit priest, they argued, should not be mixed up in secular affairs or politics nor should he be making strategic, military decisions. This was an argument that gained considerable traction in the Society of Jesus reeling from the deaths of their fellow Jesuits and in which, as we have seen, such activities were already prohibited.

The indigenous allies of the Spaniards meanwhile, well aware that they could be the next to be targeted by Anganamon, were pushing for a strong and united punitive response. The peace-process was now balanced on a knife edge. The responsibility for the deaths of his Jesuit confrères and subordinates was clearly Valdivia's, so in accepting this, should he withdraw from his political role and limit his counsel to matters spiritual as the Constitutions and instructions of the Society of Jesus required, or should he push ahead and try to finish what he started? Courageously Valdivia chose the latter, and after a swift and punitive response by the indigenous allies of the Spanish and troops from nearby forts-a show of strength crucial to the success of the so-called defensive war-the warriors of Anganamon were defeated and over one-hundred captives from Elicura were released. ${ }^{73}$ Remarkably, further disaster was averted and the frontier settled into an uneasy peace.

Valdivia continued to counsel the viceroy in Lima and the king in Spain with regard to the situation on the frontier. His counsel, however, became ever more defensive as he found himself having to defend both his own actions as well as the strategy of defensive war itself. Even in the midst of his own shock at the deaths of his confrères (arguably caused by his own mistaken judgement), he reported how these "holy men" offered their lives "with such glorious martyrdom for the glory of God our Lord and in the service of His Majesty, and for the zeal for the salvation of the souls of those pagans." ${ }^{\prime 4}$ They had, he argued, "irrigated the earth with their blood, leaving their companions with the hope

73 Valdivia, "Carta a Felipe III, [...] 20 de febrero de 1613," 194.

74 Ibid. 
of harvesting the fruit from that irrigation and desirous of imitating them, envious that they had been the first [martyrs of Chile]." ${ }^{.5}$

Notwithstanding the discourse of martyrdom, however, it became hard to distinguish between counsel and apologia as his advice to the king-that the frontier was pacified-now diametrically opposed that of the governor who was appealing for thousands of more troops to be sent to wage and win the necessary war. ${ }^{76}$ Time and again, even to his last communication to the king written in Spain to defend the defensive war between the years 1621-22 he felt compelled to reiterate the same arguments and explain again the circumstances behind what had happened. Notwithstanding the fact that Valdivia had effectively succeeded in bringing temporary peace (of sorts) to the frontier, albeit at a high cost to the Society of Jesus, this was not a peace that was acceptable to his opponents. Nor was the very fact that he had exchanged spiritual counsel for secular agency acceptable any longer to his order.

The intermittent support given to Valdivia's project at various stages by his Jesuit brethren was increasingly challenged from within the Society. Torres Bollo, the provincial of Paraguay and Valdivia's immediate superior and other influential Jesuits of Paraguay and Peru became very uneasy about the Society's ongoing investment in Spanish military and political strategy and began to favor its disassociation from the so-called defensive war. Torres Bollo's successor, Pedro de Oñate (d.1646; in office, $1615^{-24}$ ) became a vigorous opponent of Valdivia's continued political involvement. After Acquaviva's death in 1615, the newly elected superior general, Muzio Vitelleschi (1563-1645; in office 1615-45), rescinded Valdivia's authority to act independently as a government agent and in 1621, much to the Jesuit's frustration, ordered him to remain in Spain after his return in $1620 .{ }^{77}$ The ear of the new king Philip IV was with other counsellors, and on 13 April 1625 the strategy of defensive war was finally ended by royal decree. ${ }^{78}$

\footnotetext{
75 Ibid.

76 Ibid., 198-99.

77 Díaz Blanco, Alma en la palabra, 43-44.

78 Korth, Spanish Policy in Colonial Chile, 161.
} 